\title{
Gender Differences in Intimate Partner Violence via Electronic Communication Technology: An Exploratory Study of Older Adolescents and Young Adults
}

\author{
Connie Hassett-Walker ${ }^{(1)}$ \\ Department of Criminal Justice, Kean University, Union, NJ, US \\ Email: chassett@kean.edu
}

How to cite this paper: Hassett-Walker, C. (2019). Gender Differences in Intimate Partner Violence via Electronic Communication Technology: An Exploratory Study of Older Adolescents and Young Adults. Psychology, 10, 1663-1687.

https://doi.org/10.4236/psych.2019.1012110

Received: June 23, 2019

Accepted: September 22, 2019

Published: September 25, 2019

Copyright () 2019 by author(s) and Scientific Research Publishing Inc. This work is licensed under the Creative Commons Attribution International License (CC BY 4.0).

http://creativecommons.org/licenses/by/4.0/

\begin{abstract}
Much work has been done on factors that contribute to intimate partner violence (IPV), including growing up in a violent home and the role of peers. Despite the ascendency in the past decade of the Internet and social media in modern life, research on how electronic communication technology (ECT) facilitates IPV is still in the early stages. Prior research suggests differences between males and females in both IPV, and in electronic communication as relates to dating violence. The present study examined gender differences in relationship violence and ECT-usage among young women and men ages 18 to 30 that were dating, engaged and married. This study builds on earlier research that used samples of dating adolescents. Neither gender nor ECT was a strong predictor of IPV. Aggression towards peers, and peers' IPV experiences, were positive, moderate, and consistently significant predictors of IPV. Implications for prevention and intervention programming are discussed.
\end{abstract}

\section{Keywords}

Intimate Partner Violence, Adolescent, Young Adult, Electronic Communication Technology, Peers

\section{Introduction}

About 32 percent of women, and 14 percent of men, experience at least one act of physical violence from an intimate partner during their lifetime (Breiding, Smith, Basile et al., 2014). Use of electronic technology such as text messaging, and social media like Instagram and Facebook, has become increasingly common (UCLA Center for Communication Policy, 2003; Lenhart \& Madden, 
2007), particularly among young people (Draucker \& Martsolf, 2010). However, research on how intimate partner violence (IPV) occurs over electronic communication technology (ECT) is still in the early stages. It is not fully understood, for instance, how ECT increases relationship violence if it does increase it and whether there are gender differences in ECT-facilitated IPV perpetration and victimization. Because there are different factors that contribute to IPV by gender, it is plausible that there may be gendered differences in ECT-facilitated relationship violence.

This paper presents the results of an exploratory study of how ECT may facilitate relationship violence. Both Zweig, Dank, Lachman et al. (2013) and Stonard, Bowen, Walker et al. (2017) have found gender differences in ECT usage as relates to relationship (i.e. dating) violence among adolescents. The present study builds on earlier work by examining gender differences in ECT usage and its facilitation of IPV perpetration and victimization with a sample of older adolescents and young adults. First presented is the theoretical framework through which IPV can be viewed.

\section{Theoretical Framework}

\subsection{Traditional Feminist Theory about IPV: Men as Perpetrators}

The traditional feminist framework for understanding intimate partner violence is that men batter women to maintain power and control over them; and that IPV is an extreme extension of American society's patriarchal culture (Cannon \& Buttell, 2016; Dobash, Dobash, Wilson et al., 1992; Langhinrichsen-Rohling, 2010; Yllo, 2005). Ferree (1990: p. 866) writes that "male dominance within families is part of a wider system of male power". Through this view, most individuals victimized through IPV are female (Smith, Chen, Basile et al., 2017; Hayes, 2013). One type of IPV, intimate terrorism, can involve physical and sexual violence combined with other tactics aimed at controlling the victim such as emotional and economic abuse, threats, manipulation via children, and victim-blaming (Johnson, 2011). Perpetrators of IPV-intimate terrorism particularly-in heterosexual couples are more likely, although not exclusively, to be male (Graham-Kevan \& Archer, 2003; Johnson, 2006; Dobash et al., 1992). Relatedly, Reed, Ward, Tolman et al. (2018) found that adolescents that endorsed gender stereotypes about dating_-"girls and women are expected to prioritize romantic relationships, act passively in their relationships, and be sexually appealing but not 'too' sexually active... [boys and men] should be in control and assertive in their relationships, prioritize sex over romantic attachment, and treat girls and women as sexual objects" (p. 3)-were more likely to perpetrate abuse against dating partners via ECT.

\subsection{Women's IPV Perpetration}

Researchers (e.g. Miller \& Meloy, 2006; Graham-Kevan \& Archer, 2005; Swan \& Snow, 2002; Dowd, Leisring, \& Rosenbaum, 2005) have also examined women's 
IPV perpetration. Some family violence research indicates that females may be as violent as males in relationships (e.g. Swahn, Simon, Arias et al., 2008; Johnson, 2006; Straus, 2004; Archer, 2000; Straus, 1999; O’Leary, Barling, Arias et al., 1989; Straus \& Gelles, 1986; Straus, 1983); although relationship-aggressive females may be involved in relationships in which there is mutual, if less serious, violence (e.g. Johnson, 2006; Arriaga \& Foshee, 2004). Kimmel (2002) has noted that there are "more than 100 empirical studies or reports that suggest that the rates of domestic violence are equivalent" (p. 1333) for female and male victims. Some research suggests that young females and males may be equally likely to be physically aggressive with dating partners (Mulford \& Giordano, 2008; O’Keefe, 2005). Other scholarship (Feiring, Deblinger, Hoch-Espada et al., 2002) has shown that adolescent females perpetrate more physical aggression than do teenage males. Data from the 2011 Youth Risk Behavior Survey found little difference in percentages of male and female teenagers (approximately 9\% each) who had physically and deliberately struck their girlfriend or boyfriend during the prior year (CDC, 2012).

Some of the seeming gender equality in IPV perpetration may be due to methodological approaches (Johnson, 2006; Swan \& Snow, 2002). Studies that show that women perpetrate violence against their intimate partners as much as men do (e.g. Straus, 1999) are more likely to have used community data (Straus \& Gelles, 1986) and instruments such as the Conflict Tactics Scale (Straus, 1979), which has been criticized for lack of measure of the context and motivation behind IPV actions (Schwartz, 2000). By contrast, research that reveals that males are the predominant IPV offenders tend to involve police, shelter, or court data (Johnson, 2006).

Data showing that women also perpetrate IPV aside, women's violence against their partners occurs within a society that actively maintains a power imbalance between males and females (Stark, 2007; White \& Kowalski, 1994). Women may commit IPV against partners in reaction to male violence against them (Swan, Gambone, Caldwell et al., 2008; Stuart, Moore, Coop Gordon et al., 2006; Swan \& Snow, 2002); to defend either themselves or their children, or both (Miller \& Meloy, 2006; Stuart et al., 2006; Molidor \& Tolman, 1998); or in retaliation for past violent victimization (Stuart et al., 2006). Other scholarship points to men typically having greater physical strength than their female partners; and using violence against their partners more frequently than women do (Giles-Sims, 1983; Koss et al., 1994). Male violence also tends to be more severe than female-perpetrated violence (Hettrich \& O'Leary, 2007; Langhinrichsen-Rohling, Neidig, \& Thorn, 1995), and more likely to cause injury to their female partners than vice-versa (Swan et al., 2008; Archer, 2000; Langhinrichsen-Rohling et al., 1995; Cantos, Neidig, \& O’Leary, 1994; Koss, Goodman, Browne et al., 1994; Feld \& Straus, 1989; Giles-Sims, 1983). Female victims of IPV are more likely to experience fear of being hit (Cantos et al., 1994). It is important to not ignore women's perpetration of violence in relationships (Straus, 1999), as it may contribute to a male partner's retaliation (Stith, Smith, Penn et al., 2004), which can 
in turn lead to greater injury to the woman (e.g. Archer, 2000).

\section{Relationship Violence via Electronic Communication Technology}

ECT can play a key role throughout the duration of romantic relationships, particularly among young people (e.g. adolescents, young adults); and psychological abuse of a romantic partner can occur both in person and via ECT (Langhinrichsen-Rohling \& Capaldi, 2012), with ECT facilitating "a continuum of abusive behavior" (Stonard et al., 2017: p. 2087). An IPV relationship may include an array of abusive behaviors-"psychological, physical, sexual, stalking, cyberaggression" - that all need to be addressed (Langhinrichsen-Rohling \& Capaldi, 2012: p. 411).

While research on the role of ECT in relationship violence is still relatively new, some scholarly work has been done (e.g. Cutbush, Williams, Miller et al., 2018; Reed et al., 2018; Stonard et al., 2017; Zweig et al., 2013; Draucker \& Martsolf, 2010), particularly around adolescent dating relationships. Electronic IPV harassment can include calling a partner's phone multiple times a day to check up on them; going through a partner's text or voicemail messages to see who they have been communicating with; and leaving a partner threatening messages if they (the partner) do not call back (Draucker \& Martsolf, 2010). Surveying middle and high school students $(\mathrm{n}=5647)$, Zweig et al. (2013) found that about one-fourth of their respondents said they had been victimized via some type of ECT-related IPV during the prior 12 months. They also found gender differences in IPV, with female students indicating more sexual ECT-related IPV victimization. Other studies (i.e. Picard, 2007; Draucker \& Martsolf, 2010) have found ECT-facilitated IPV victimization of dating partners, specifically receiving menacing text messages, emails, and voicemail messages; and being bothered on social media sites like Facebook.

\section{Other IPV Contributing Factors}

Key factors for relationship violence, including dating violence, that have been identified in prior research include violence witnessed and experienced in the home while growing up (Lichter \& McCloskey, 2004; Foshee, Benefield, Ennett et al., 2004; Foshee, Ennett, Bauman et al., 2005; Vézina \& Hébert, 2007); peers (e.g. Arriaga \& Foshee, 2004; Foshee et al., 2004; Foshee, Reyes, \& Ennett, 2010; Swart, Seedat, Stevens, \& Ricardo, 2002; Adelman \& Kil, 2007; Capaldi, Dishon, Stoolmiller et al., 2001; Schnurr, 2009); among young people, level of parental monitoring (Lavoie, Hébert, Tremblay et al., 2002; Leadbeater, Banister, Ellis et al., 2008); law breaking (Gorman-Smith, Tolan, Sheidow et al. 2001); sexual orientation (Halpern, Young, Waller et al., 2004); and race and ethnicity $(\mathrm{Cu}-$ nradi, 2009; Howard \& Wang, 2003; Lormand, 2009; Yan, Howard, Beck et al., 2010). Individuals who grow up in a violent home may learn that violence is an acceptable way to resolve conflict. How this plays out may differ by gender (Wolf 
\& Foshee, 2003; Kinsfogel \& Grych, 2004). Males who observe inter-parental violence while growing up may view aggression as appropriate in a relationship, whereas females may better understand the potential for harm when witnessing violent parental conflict (Kinsfogel \& Grych, 2004).

A meta-analysis by Stith et al. (2004) found that drug and alcohol use were both related to IPV perpetration with moderate to large effect sizes. Gender differences have been found in substance use among couples engaged in relationship violence (e.g. Ackard, Neumark-Sztainer, \& Hannan, 2003; Coker, McKeown, Sanderson et al., 2000; Kelly, Cheng, Peralez-Dieckmann et al., 2009; Lormand, 2009; Chase, Treboux, \& O’Leary, 2002; Tontodonato \& Crew, 1992). In adolescence, alcohol use by girls can increase vulnerability to physical dating violence victimization (Brooks-Russell et al., 2013). Young female victims of dating violence may be more likely to binge drink and use hard drugs such as cocaine (Howard \& Wang, 2003). Foshee et al. (2010) found that smoking marijuana increased the risk that adolescent females perpetrate dating violence, but decreased the likelihood that teenage males would be aggressive with dates. By contrast, Chase et al. (2002) found that earlier-life drug use and pot smoking may be associated with increased risk of relationship aggression among males. The use of marijuana or alcohol may increase situational risk for victimization, including IPV, as use of such substances typically occurs in environments with less supervision (e.g. from parents) (Brooks-Russell et al., 2013).

\section{Present Study}

In summary, while many factors related to partner violence have been examined, more research is needed on how ECT facilitates IPV and whether there are gender differences in IPV perpetration and victimization as relates to ECT usage. The present study builds on earlier work (i.e. Zweig et al., 2013; Stonard et al., 2017) that found gender differences in ECT connected to dating violence among samples of adolescents, by using a sample of older teenagers and young adults with different types of relationship statuses (i.e. dating, engaged, married, married-but-separated). Among those earlier studies' findings were that male teenagers experienced more dating violence victimization (Zweig et al., 2013); and that female adolescents were more likely to control dating partners' social media accounts, including asking for partners' passwords and requiring that female friends be deleted from their partners' social media (Stonard et al., 2017). Female adolescents also experienced greater insecurity and anxiety around ECT communication with dating partners (Stonard et al., 2017).

The research questions that ground the present study are as follows:

RQ1: Does ECT usage, including ECT-facilitated aggression, increase IPV?

RQ2: Are there gender differences in ECT-facilitated IPV?

\section{Research Methodology}

After receiving approval from the university's Institutional Review Board, the 
investigator administered a survey online to young adults ages 18 to 30 years old who had registered with the StudyResponse Center for Online Research ${ }^{1}$, a non-profit organization formerly housed within Syracuse University's School of Information Studies. StudyResponse provides investigators with random samples drawn from a database of tens of thousands of individuals of differing races and ethnicities, ages, and professions. The investigator requested a sample of 500 individuals ages 18 to 22 years. The age parameters were eventually expanded up to 30 years old because of a low initial response rate (i.e. fewer than 60 responses). At the close of the survey, data were ultimately gathered from 476 respondents.

\subsection{Sample Size and Description}

A total of 239 males and 237 females took the survey (total sample size $n=476$ ). Average age for both genders was just over 26 years old (not shown in the table). Three-quarters (76\%) of respondents self-identified as Caucasian; $13 \%$ were Asian or Pacific Islander; 6\% were African American; 7\% were Hispanic; and 5\% were Native American. Race/ethnicity data were gathered by Study Response. Because race/ethnicity indicators were provided individually (e.g. Are you African American, yes or no? Are you Hispanic, yes or no?), multi-racial respondents would have answered "yes" to more than one question. (Three individuals, for example, indicated they were both African American and Hispanic.) As such, the percentages listed above and in Table 1 total greater than $100 \%$.

Educational attainment ranged from having a terminal degree like a $\mathrm{PhD}(2 \%)$ to being a high school graduate (9\%). Forty-four percent of respondents had a four-year college degree. The majority of respondents (93\%) described themselves as heterosexual. Three percent indicated they were bisexual, and $4 \%$ described their sexual orientation as homosexual. Nearly $87 \%$ grew up in two-parent, biological families. The majority of the sample was either dating (51\%) or married $(40 \%)$. Smaller percentages of respondents were engaged $(6 \%)$ or married but separated (3\%). The breakout of relationship status by gender is shown in Table 2.

\subsection{Dependent Variables}

Composite indices for physical IPV victimization (Y1) and relational IPV victimization (Y2), and physical IPV perpetration (Y3) and relational IPV perpetration (Y4), were created using questions adapted from both the Revised Conflict Tactics Scale, the physical assault scale items (CTS2; Straus, Hamby, Boney-McCoy et al., 1996); and the Healthy Youth Survey questionnaire (Leadbeater, Banister, Ellis et al., 2008). The CTS2 has been used in previous IPV and teen dating violence research (Schnurr \& Lohman, 2013), and the scales have good psychometric properties (Vega \& O'Leary, 2007). Physical IPV victimization questions included my current partner has pushed or shoved me in order to get me to do what s/ he wants, my current partner has threatened physical harm in hhtp://www.studyresponse.net/index.htm. 
Table 1. Sample race and ethnicity.

\begin{tabular}{ccc}
\hline Race/Ethnicity & Number answering "yes"* & Percentage answering "yes" \\
\hline Caucasian & 361 & 75.8 \\
African American & 28 & 5.9 \\
Hispanic & 34 & 7.1 \\
Asian or Pacific Islander & 60 & 12.6 \\
Native American & 22 & 4.6 \\
Other Race & 5 & 1.1 \\
\hline
\end{tabular}

*Because respondents could answer yes to more than one race/ethnicity question, the numbers of "yes" responses total greater than 476 (the sample size), and percentages total higher than $100 \%$.

Table 2. Respondent relationship status by gender.

\begin{tabular}{ccc}
\hline & Male & Female \\
& Count (\%) & Count (\%) \\
\hline Engaged & 136 & 106 \\
& $(56.9 \%)$ & $(44.7 \%)$ \\
Married & 9 & 20 \\
& $(3.8 \%)$ & $(8.4 \%)$ \\
Married, but separated & 88 & 103 \\
& $(36.8 \%)$ & $(43.5 \%)$ \\
Total & 6 & 8 \\
& $(2.5 \%)$ & $(3.4 \%)$ \\
& 239 & 237 \\
& $(100 \%)$ & $(100 \%)$ \\
\hline
\end{tabular}

order to control me; and my current partner has tried to get his/ her own way through physical intimidation. Question wording was modified to reflect physical IPV perpetration; for example, I have pushed or shoved my current partner to get him/ her to do what I want. Some additional perpetration questions were also asked (e.g. How often have you slapped your current partner in the past six months?).

Relational IPV victimization questions included my partner tries to make me feel jealous as a way of getting back at me, when my current partner wants something, s/he will ignore me until I give in; my partner has threatened to break up with me in order to get me to do what s/ he wants, and my partner doesn't pay attention to me when s/ he is mad at me (To reflect relational IPV perpetration, question wording was modified, for example, as follows: I try to make my current partner jealous when I am mad at him/ her.) Reliability analyses were performed prior to creating four composite indices (Y1-Y4). All Cronbach alpha statistics were greater than $0.70^{2}$, suggesting that the individual measures loaded well together.

${ }^{2}$ Cronbach's alphas for the IPV dependent variable constructs were as follows: Victimization_physical, 3 items: 0.883; Victimization_relational, 4 items: 0.825; Perpetration_physical, 5 items: 0.906; Perpetration_relational, 4 items: 0.733 . 


\subsection{Main Independent Variable}

\section{Electronic Aggression}

Questions pertaining to electronic IPV victimization (X1) and perpetration (X2) (e.g. use of various technologies to monitor or control an intimate partner, or be monitored/controlled by a partner; direct verbal or emotional aggression towards an intimate partner, or having verbal or emotional aggression directed at them) were adapted from the work of Draucker and Martsolf (2010), who found that electronic communication contributes to IPV among dating partners. After running reliability analyses and finding Cronbach alpha scores greater than 0.70 , ten items each were combined into an electronic victimization composite index, $\mathrm{X} 1$ (e.g. Has your current partner displayed emotional or verbal aggression towards you via text messaging? Monitored or controlled you via social networking like Facebook?); and an electronic perpetration composite index, X2 (e.g. Have you ever displayed emotional or verbal aggression towards current partner via text messaging? Monitored or controlled your current partner via social networking like Facebook?).

\subsection{Other Independent Variables}

\subsubsection{Peer Relationships and Aggression}

Having friends who have experienced IPV victimization may be related to one's own IPV experiences (Foshee et al., 2004). Tapping into Foshee's work, composite indices of peers' IPV (X3) and aggression towards peers (X4) were created. Survey questions asked about the number of friends respondents have who are victims and/or perpetrators of IPV (e.g. Have any of your friends ever been victims of dating violence? How many friends have told you a date has been violent/ aggressive to him or her in the past six months? Have any of your friends ever been perpetrators of dating violence or aggression? How many friends have told you that they have perpetrated dating violence or aggression in the past six months?).

Questions about respondents' aggression with friends they are not dating (e.g. Have you engaged in any physical fights with your friends [ whom you were not dating] in the past six months? How often would you say you have yelled and screamed insults at a friend because you were mad at them?) were grounded in the work of Foshee et al. (2004) and Foshee et al. (2010) who found that aggression against one's friends was related to one's own IPV perpetration.

\subsubsection{Substance Use}

Substance use measures were adopted from standard questions used in established longitudinal surveys (e.g. NLSY97; United States Department of Labor, 2013). Respondents were asked on how many days they used marijuana during the past month (X5). Binge drinking (i.e. five or more drinks on one occasion) and hard drug use (e.g. cocaine) during the prior 30 days were combined into a composite index ${ }^{3}$ (X6).

${ }^{3}$ Reliability analyses revealed that marijuana use did not load well with binge drinking and hard drug use. Thus the substance use construct (binge drinking, hard drug use) and marijuana use variable are treated separately in the regression analyses. Collinearity diagnostics show that they are not collinear (i.e. VIF scores below 4.0). 


\subsubsection{Sexual Orientation and Relationship Status}

Respondents were asked about their sexual orientation (heterosexual, bisexual, homosexual). Because the majority of respondents self-selected heterosexuality, orientation was recoded into the dichotomous variable heterosexual yes/no (X7). Respondents were also asked about their relationship status (X8), the response choices for which followed a chronological progression: dating, engaged, married, and married-but-separated.

\subsubsection{Family of Origin Issues}

Questions operationalizing family of origin issues included witnessing violence between one's parents (X9; e.g. one parent hitting another; Arriaga \& Foshee, 2004; Foshee et al., 2005); and being hit by an adult with the intention of harm (X10; Foshee et al., 2004; Foshee et al., 2005). A composite index of parental monitoring was also created (X11; e.g. How much did your parents really know where you go at night? How much did your parents really know where you were most afternoons after schoo? Did your parents know who your friends were? Barber, Olsen, \& Shagle, 1994; Leadbeater et al., 2008).

\subsubsection{Prior Arrest}

Questions about both general and violent delinquency (e.g. number of arrests in the past 30 days) were combined into a composite index, prior arrest (X12).

\subsection{Control Variables}

Respondents' race/ethnicity, education level, age and gender are also included in the analyses. Because a majority of the sample indicated they were of the Caucasian race, the race/ethnicity variables were recoded into White/not White for the regression analyses.

\subsection{Analyses}

All analyses were performed in SPSS v.21 software. The data were analyzed via t-tests, chi square, Pearson correlation coefficient and OLS regression analyses. Eight regressions were performed, two for each dependent variable construct with electronic victimization (X1) and electronic perpetration (X2) entered separately into each model to avoid issues with collinearity. Qualitative responses to an open-ended question about IPV experiences were printed out and examined for differential themes by gender.

\section{Results}

\subsection{Descriptive Results}

\subsubsection{IPV Victimization Experiences}

In terms of physical IPV victimization, 71\% or higher of respondents indicated that their current partner did not threaten physical harm to control them; attempt to get their way via physical intimidation; or push or shove them (the respondent) to get their way. (See also Table 3.) Twenty-nine percent of respondents indicated that these behaviors were true or sometimes true. Relational 
Table 3. Descriptive statistics of the dependent, independent, and control variables.

\begin{tabular}{ccccc}
\hline & Min. & Max. & Mean & SD \\
\hline $\begin{array}{c}\text { Dependent Variables } \\
\text { Y1, physical victimization }\end{array}$ & 1.00 & 3.00 & 1.42 & 0.64 \\
Y2, relational victimization & 1.00 & 3.00 & 1.44 & 0.55 \\
Y3, physical perpetration & 1.00 & 4.00 & 1.39 & 0.66 \\
Y4, relational perpetration & 1.00 & 3.00 & 1.41 & 0.49
\end{tabular}

Independent Variables

Electronic aggression

$\begin{array}{lllll}\text { X1, Electronic victimization } & 1.00 & 1.34 & 1.06 & 0.09 \\ \text { X2, Electronic perpetration } & 0.06 & 0.81 & 0.23 & 0.16\end{array}$

Peer relationships and aggression

$\begin{array}{lllll}\text { X3, Peers' IPV } & 1.00 & 4.00 & 1.37 & 0.63 \\ \text { X4, Peers, aggression towards } & 1.00 & 3.63 & 1.35 & 0.43\end{array}$

Substance use

$\begin{array}{lllll}\text { X5, MJ use } & 1.00 & 5.57 & 1.29 & 0.87 \\ \text { X6, Hard drug use \& binge drinking } & 1.00 & 4.80 & 1.35 & 0.57\end{array}$

Sexual orientation and relationship status

$\begin{array}{lcccc}\text { X7, Sexual orientation } & 0 & 1 & 0.92 & 0.27 \\ \text { X8, Relationship status } & 1.00 & 4.00 & 1.95 & 1.01\end{array}$

Family of origin issues

$\begin{array}{lllll}\text { X9, Witnessed parental IPV } & 1.00 & 4.00 & 1.36 & 0.74 \\ \text { X10, Experienced child abuse } & 1.00 & 4.00 & 1.55 & 0.93 \\ \text { X11, Lack of parental monitoring } & 1.00 & 5.00 & 2.64 & 1.26\end{array}$

Law Breaking

$\begin{array}{lllll}\text { X12, Arrested } & 1.00 & 4.69 & 1.11 & 0.42\end{array}$

Demographic controls

\begin{tabular}{lcccc} 
X13, Race & 0 & 1 & 0.76 & 0.43 \\
X14, Education level & 1 & 8 & 4.79 & 1.42 \\
X15, Age & 18 & 30 & 26 & 2.68 \\
X16, Gender & 0 & 1 & 0.51 & 0.50 \\
\hline
\end{tabular}

IPV victimization of respondents was more common. While about two-thirds of respondents indicated that their partners did not engage in relational aggression against them, $31 \%$ said that partners would try to make them jealous as a way to get back at them; 35\% indicated that their partners would ignore them until they gave in; $26 \%$ said that their partners threatened to break up with them to get what they wanted; and 39\% indicated that their current partner would not pay attention to them when mad at them (the respondent). 
Table 4. Electronic aggression victimization (X1) and perpetration (X2) by gender and technology type.

\begin{tabular}{|c|c|c|c|c|}
\hline & & ercentage & nding "ye & \\
\hline & & Males & Females & $x^{2}$ \\
\hline Victimization & & & & \\
\hline & $\begin{array}{l}\text { My current dating partner has monitored or } \\
\text { controlled me via social media or technology }\end{array}$ & 28.7 & 18.5 & $6.69^{* *}$ \\
\hline & - by cell phone & 21.9 & 16.4 & 2.34 \\
\hline & - by text messaging & 19.4 & 16.4 & 0.73 \\
\hline & - by instant messaging & 17.3 & 12.1 & 2.56 \\
\hline & - by social networking & 20.3 & 9.1 & $11.72^{* *}$ \\
\hline & $\begin{array}{l}\text { My current dating partner has displayed } \\
\text { emotional or verbal aggression towards me via } \\
\text { social media or technology }\end{array}$ & 25.3 & 19.4 & 2.36 \\
\hline & - by cell phone & 15.6 & 16.8 & 0.12 \\
\hline & - by text messaging & 20.7 & 15.5 & 2.10 \\
\hline & - by instant messaging & 11.8 & 11.2 & 0.04 \\
\hline & - by social networking & 14.8 & 6.9 & $7.49^{* *}$ \\
\hline Perpetration & $\begin{array}{l}\text { I have monitored or controlled my current } \\
\text { dating partner via social media or technology }\end{array}$ & 28.3 & 24.1 & 1.03 \\
\hline & - by cell phone & 20.7 & 22.8 & 0.32 \\
\hline & - by text messaging & 18.6 & 17.2 & 0.14 \\
\hline & - by instant messaging & 16.5 & 13.8 & 0.65 \\
\hline & - by social networking & 19.8 & 15.5 & 1.50 \\
\hline & $\begin{array}{l}\text { I have displayed emotional or verbal aggression } \\
\text { towards my current partner via social media or } \\
\text { technology }\end{array}$ & 24.5 & 20.7 & 0.96 \\
\hline & - by cell phone & 18.1 & 19.4 & 0.12 \\
\hline & - by text messaging & 15.6 & 16.4 & 0.05 \\
\hline & - by instant messaging & 12.7 & 9.9 & 0.88 \\
\hline & - by social networking & 11.4 & 6.0 & $4.22^{*}$ \\
\hline
\end{tabular}

${ }^{\mathrm{a}} \mathrm{Questions}$ are adopted and modified from Draucker \& Martsolf (2010), Table 2. Chi square statistical significance is indicated as follows: ${ }^{*} p \leq 0.05,{ }^{* *} p \leq 0.01$.

\subsubsection{IPV Perpetration Experiences}

In terms of physical IPV perpetration, while most respondents (71\%) had never pushed or shoved their current partner; $17 \%$ had pushed/shoved their partner once or twice; and $12 \%$ had pushed/shoved their partner three or more times. Ten percent of respondents had slapped their current intimate partner once or twice during the past six months; and $8 \%$ had slapped their current partner three or more times. Sixteen percent of respondents had grabbed their current partner once or twice during the prior six months; and 10\% had grabbed their partner three or more times. 
In terms of relational IPV perpetration, a minority of respondents indicated that it was true or somewhat true that they cheated on their partner because they were angry at him or her (24\%); flirted with other people in front of their partner when mad at him/her (21\%); tried to make their current partner jealous when mad at him/her (31\%); and gave their partner the silent treatment when mad at him/her (46\%).

\subsubsection{ECT-Facilitated IPV}

Respondents answered a variety of questions about myriad ECT-facilitated IPV, both victimization and perpetration experiences (See Table 4.)

\subsubsection{Peers' IPV Victimization and Perpetration}

While the majority of respondents (73\%) said that none of their friends had been victims of IPV, $27 \%$ indicated that they had friends who had ever been victimized through IPV. Nineteen percent of respondents said that one friend told them that a date or partner had been aggressive to them (the respondent) in the past six months; and $12 \%$ indicated that two or more friends had told them this. Eighteen percent of respondents said that at least one of their friends had ever been violent towards a date or their partner; $14 \%$ of respondents had one friend tell them they had been violent towards a date or partner during the past six months; and 7\% had two or more friends say they had been violent towards a date or partner during the prior six months.

\subsubsection{Aggression towards Peers}

Fourteen percent of respondents had engaged in physical fighting with non-dating friends during the previous six months. Ten percent had had one or two fist fights with friends, and $4 \%$ had three or more physical altercations with friends during the prior six months. During the six months prior to taking the survey, a minority of respondents indicated they had engaged in the following aggressive behaviors towards friends: screamed insults because they were angry at their friend (17\% 1 - 2 times; $6 \% 3$ or more times); made nasty comments because they were angry at their friend (26\% $1-2$ times; $10 \% 3$ or more times); pushed or slapped their friend because they were angry at them (11\% $1-2$ times; $6 \% 3$ or more times); hit with the intention of hurting because they were angry at their friend (11\% 1 - 2 times; $4 \% 3$ or more times); and twisted a friend's arm or pulled their hair because they were mad at them (11\% 1 - 2 times; $5 \% 3$ or more times).

\subsubsection{Substance Use Experiences}

Eighty percent of respondents had ever had a drink of alcohol; and 50\% had drank five or more alcoholic drinks in one setting during the month prior to the survey (not shown in table format). Thirty-two percent of respondents had ever used marijuana; and 16\% reported marijuana usage during the past month. Six individuals indicated that they smoked marijuana every day. Only 14\% of respondents indicated that they had ever used cocaine or other hard drugs; and $9 \%$ 
had used such substances during the prior month.

\subsubsection{Family of Origin Issues}

Most respondents (76\%) had never seen one of their parents hit the other parent. Fifteen percent had seen one parent strike the other parent once or twice; and nine percent of respondents had witnessed one parent hit the other three or more times. In terms of experiencing child abuse, sixty-eight percent of respondents had never been deliberately hit by an adult while growing up; $17 \%$ had been hit once or twice; and $15 \%$ had been hit three or more times. Fifty-two percent of respondents said that while they were a teenager, their mother or female guardian always or usually knew where they were when they were not at work or school. Twenty-two percent indicated that their mother/female guardian knew where they were sometimes; and $26 \%$ said their mother or female guardian rarely or never knew where they were when they were not at work or school. (Similar percentages were found for two other "parental monitoring" questions; i.e. whether the respondent's parents/guardians knew where they were at night, and if their parents/guardians knew who the respondent's friends were).

\subsubsection{Arrest History}

Only small percentages of respondents had ever been arrested for a violent (8\%) or non-violent $(10 \%)$ incident. Two percent of respondents had been arrested once during the prior six months; and $7 \%$ had been arrested two or more times during the prior six months.

\subsection{Gender Differences in Respondents' Experiences with IPV}

Male respondents scored higher than females (i.e. more relationship aggression) on all IPV dependent variables (see Table 5). When subsequent chi square tests were performed on the individual measures (e.g. threatened, were threatened, pushed or shoved, were pushed or shoved) that were used to create the indices shown in the table, males also scored higher on most indicators (not shown in table format), although the results were not always statistically significant.

Table 5. Gender differences in physical and relational IPV in current relationship.

\begin{tabular}{|c|c|c|c|}
\hline & Gender & Mean & Std. Deviation \\
\hline \multirow{2}{*}{ Y1, Physical victimization } & Male & 1.4899 & 0.67228 \\
\hline & Female & 1.3430 & 0.61176 \\
\hline \multirow{2}{*}{ Y2, Relational victimization } & Male & 1.5051 & 0.57591 \\
\hline & Female & 1.3743 & 0.52296 \\
\hline \multirow{2}{*}{ Y3, Physical perpetration } & Male & 1.4705 & 0.71078 \\
\hline & Female & 1.3159 & 0.59746 \\
\hline \multirow[t]{2}{*}{ Y4, Relational perpetration } & Male & 1.4711 & 0.55369 \\
\hline & Female & 1.3566 & 0.41962 \\
\hline
\end{tabular}

All t-statistics for the above tests were significant at $p \leq 0.05$. 
Respondents were asked an open-ended question about their IPV experiences. A comparison of feedback revealed some differences by gender. As seen below, male respondents made fewer comments than did female respondents, and did not directly comment on either perpetrating or being victimized by relationship violence. In fact, the only IPV experiences the male respondents commented on were those of other people. By contrast, the female respondents were more expressive, admitting to both IPV victimization and perpetration as well as past child abuse experiences.

\subsubsection{Male Comments about IPV Experiences}

Male comments included the following: "I have seen siblings, family members, and friends deal with abuse in relationships." "I just don't know how someone can stay or keep going back to an abusive relationship." "Raised in an affluent Asian community, violence against partners was something I only found out about in movies and then the rape survivors I had met in college. I had everything in my favor to keep me from being an abusive man." "I owe any restraint from violence in my life to my trust in Jesus." "I usually think this type of behavior is associated with dysfunctional relationships, and not ones that are 'normal'." "I hate aggression.".

\subsubsection{Female Comments about IPV Experiences}

Female comments included the following: "Been with partner so long that some of these behaviors are 10+ years old." "I had an aggressive dating partner more than three years ago." "I haven't heard many real case stories of domestic violence, just the occasional general warning about it on TV." "I had an emotionally abusive boyfriend from when I was 18 to $21 \ldots$ I'm 26 now." "I have not had many violence issues in past 6 months or with current partner, but did have them with previous partners many years ago." "Past relationships were much more eventful on the partners' parts. Also, the only time I really screamed at my husband and threw a shoe was while blackout drunk during depression which I am out of. I did not try to actually hit him. Just express my frustration and scare him." "It disgusts and frightens me how ingrained and difficult it is to overcome my aggressive impulses, the great majority of which are verbal." "I believe most of my aggression issues stem directly from childhood trauma. Sexual abuse followed by death of sibling followed by years of unintentional emotional and physical abuse by my teenage mother.".

These comments suggest that female respondents are more forthcoming about IPV experiences, both victimization and perpetration, than the men are even if, as suggested by the results in Table 4, they experienced less IPV than their male counterparts.

\subsection{Gender Differences in Electronic Aggression Victimization and Perpetration}

The $\mathrm{X} 1$ and $\mathrm{X} 2$ indices were compared for males and females via t-test (not shown in table format). Males scored higher than females (X1: 1.06/males vs. 
1.04/females; X2: 0.24/males vs. 0.22/females), although the results were only significant for electronic aggression (X1). Male and female respondents' electronic aggression victimization and perpetration as per the individual survey questions are also compared in Table 5 . Those with statistically significant chi square tests are bolded.

For both victimization and perpetration, males' electronic aggression experiences were generally higher (i.e. greater percentages of "yes" responses) than were females' experiences, with a few exceptions. In terms of victimization by ECT, male respondents were significantly more likely to report being monitored and controlled via social media or technology by their partner. Males were also more likely to report having aggression directed at them via social networking sites. As for perpetration, males were more likely than females to direct aggression at a partner via social networking sites like Facebook. The only indicators on which females scored higher than males were for ECT-IPV victimization and perpetration by cell phone, and perpetration via text messaging. These results were not statistically significant, however.

\subsection{Predicting Physical and Relational IPV Victimization and Perpetration}

Correlation analyses between the dependent variables (Y1 through Y4) and the two main independent variables (X1, X2) showed that electronic aggression victimization and perpetration were both significantly $(p=0.00)$ and moderately related to the four dependent variables (not shown in table format). Pearson correlation coefficients ranged from a low of 0.22 (Y4-X2) to a high of 0.33 (Y2-X1).

\subsubsection{Research Questions 1 and 2}

As seen in the regression analyses in Table 6, addressing research question 1 electronic aggression-victimization, perpetration-was neither a strong nor consistent predictor of physical or relational IPV. The largest effect, modest at that, was for electronic victimization predicting greater relational victimization $(B=0.15)$. While correlation analyses may have suggested a moderate relationship between ECT-related IPV and IPV victimization and perpetration, those findings did not bear out in regression analyses when other factors were included in the model.

Addressing the second research question as to whether gender was a meaningful predictor of IPV, as per the results seen in Table 6 the answer is no. While the results seen earlier in Table 4 and Table 5 suggest some gender differences in both IPV and ECT-facilitated IPV, those effects were not apparent in the regression analyses.

\subsubsection{Other Findings}

Factors related to peers were much stronger predictors of IPV. In particular, aggression towards peers was a positive, moderately strong and consistently significant predictor of physical and relational IPV, both victimization and perpetration. 
Table 6. Predicting IPV victimization and perpetration.

\begin{tabular}{|c|c|c|c|c|c|c|c|c|}
\hline \multirow[b]{2}{*}{$\begin{array}{l}\mathrm{X} 1 \text {, Electronic } \\
\text { victimization }\end{array}$} & \multicolumn{2}{|c|}{$\begin{array}{l}\text { Y1, Physical } \\
\text { victimization }\end{array}$} & \multicolumn{2}{|c|}{$\begin{array}{l}\text { Y2, Relational } \\
\text { victimization }\end{array}$} & \multicolumn{2}{|c|}{$\begin{array}{l}\text { Y3, Physical per- } \\
\text { petration }\end{array}$} & \multicolumn{2}{|c|}{$\begin{array}{l}\text { Y4, Relational } \\
\text { perpetration }\end{array}$} \\
\hline & $0.08^{*}$ & - & $0.15^{* *}$ & - & $0.06 \sim$ & - & 0.04 & - \\
\hline $\begin{array}{l}\mathrm{X} 2 \text {, Electronic } \\
\text { perpetration }\end{array}$ & - & $0.08^{*}$ & - & $0.07 \sim$ & - & $0.06 \sim$ & - & 0.03 \\
\hline X3, Peers' IPV & $0.10 \sim$ & $0.10 \sim$ & $0.17^{* *}$ & $0.18^{\star *}$ & $0.14^{* *}$ & $0.14^{* *}$ & $0.12 \sim$ & $0.12 \sim$ \\
\hline $\begin{array}{c}\mathrm{X} 4 \text {, Peers, aggression } \\
\text { towards }\end{array}$ & $0.42^{* *}$ & $0.43^{* *}$ & $0.37^{* *}$ & $0.39^{* *}$ & $0.37^{* *}$ & $0.37^{* *}$ & $0.44^{* *}$ & $0.45^{* *}$ \\
\hline $\mathrm{X} 5, \mathrm{MJ}$ use & -0.02 & -0.03 & 0.01 & -0.01 & 0.03 & 0.02 & 0.03 & 0.03 \\
\hline $\begin{array}{l}\text { X6, Hard drug use \& } \\
\text { binge drinking }\end{array}$ & 0.06 & 0.06 & 0.06 & 0.07 & $0.17^{\star *}$ & $0.17^{* *}$ & 0.04 & 0.04 \\
\hline $\mathrm{X} 7$, Sexual orientation & 0.01 & 0.01 & 0.06 & $0.07 \sim$ & -0.01 & -0.01 & $0.11^{*}$ & $0.11^{*}$ \\
\hline $\begin{array}{l}\text { X8, Relationship } \\
\text { status }\end{array}$ & $0.08^{*}$ & $0.08 \sim$ & 0.02 & 0.01 & $0.07^{*}$ & $0.06 \sim$ & 0.02 & 0.02 \\
\hline $\begin{array}{l}\text { X9, Witnessed } \\
\text { parental IPV }\end{array}$ & $0.08 \sim$ & $0.09 \sim$ & -0.01 & -0.01 & $0.12^{* *}$ & $0.13^{* *}$ & -0.07 & -0.07 \\
\hline $\begin{array}{l}\text { X10, Experienced } \\
\text { child abuse }\end{array}$ & -0.02 & -0.02 & 0.07 & 0.07 & -0.04 & -0.04 & $0.14^{* *}$ & $0.14^{* *}$ \\
\hline $\begin{array}{l}\text { X11, Absence of } \\
\text { parental monitoring }\end{array}$ & $0.15^{\star *}$ & $0.14^{* *}$ & -0.07 & -0.07 & $-0.08^{*}$ & $-0.08^{*}$ & -0.07 & -0.07 \\
\hline X12, Arrested & $0.12^{*}$ & $0.12^{*}$ & 0.01 & 0.01 & $0.14^{\star *}$ & $0.13^{* *}$ & 0.06 & 0.05 \\
\hline Race & -0.05 & -0.06 & $\sim-0.07$ & $-0.08 \sim$ & -0.01 & -0.01 & -0.03 & -0.03 \\
\hline Education level & 0.04 & 0.05 & -0.04 & -0.04 & 0.04 & 0.04 & -0.04 & -0.04 \\
\hline Age & -0.05 & -0.05 & 0.01 & 0.01 & $0.06 \sim$ & $0.07^{*}$ & -0.03 & 0.03 \\
\hline Gender & -0.03 & -0.03 & -0.04 & -0.04 & -0.02 & -0.02 & -0.05 & -0.05 \\
\hline Adj. $R^{2}$ & 0.50 & 0.50 & 0.43 & 0.42 & 0.65 & 0.65 & 0.43 & 0.43 \\
\hline $\mathrm{df}$ & 15 & 15 & 15 & 15 & 15 & 15 & 15 & 15 \\
\hline F & 26.25 & 26.29 & 20.42 & 19.25 & 49.96 & 49.98 & 19.68 & 19.65 \\
\hline Sig. & 0.00 & 0.00 & 0.00 & 0.00 & 0.00 & 0.00 & 0.00 & 0.00 \\
\hline
\end{tabular}

${ }^{\star} p \leq 0.05 ;{ }^{* *} p \leq 0.01 ; \sim p \leq 0.1$ (approached significance). Collinearity diagnostics: All VIF scores were below 4.0 .

This is similar to the findings of Foshee et al. (2004) and Foshee et al. (2010) who found that aggression against peers significantly predicted IPV perpetration among dating adolescents. While the finding of being aggressive in both romantic and peer relationships seems logical (e.g. abusive individuals may be aggressive towards both friends and lovers), the connection between being aggressive towards peers while experiencing greater IPV victimization suggests a different pathway. It is possible, for instance, that respondents who did things like screaming insults at friends, or pushing/slapping friends when mad at them, also took similar action against intimate partners which resulted in retaliatory IPV victi- 
mization.

Peers' IPV experiences were also significantly related to greater IPV experiences, particularly relational victimization (Y2) and physical perpetration (Y3). One possible explanation for these findings may be that individuals involved in relationships where IPV is a factor are more likely to have peers with similar relationships (i.e. the flocking together of "birds of a feather"). Relatedly, Foshee et al. (2004) found that adolescents were at risk for dating violence victimization if they had a friend who had also experienced violence from a dating partner; and suggest that such a peer group "exposes the adolescent to potential dating partners who use violence against their partners, or the adolescent and his or her friends are doing things and going places that puts them at risk for victimization" (p. 1014).

Regarding family of origin factors, witnessing parental IPV was significantly, if modestly, related to physical IPV perpetration. Experiencing child abuse was similarly related to relational IPV perpetration. Absence of parental monitoring was related to physical victimization, and inversely related to physical perpetration. These findings, particularly those family factors related to IPV perpetration, bring to mind cycle of violence theory (e.g. Widom, 1989); that is, individuals that witness or experience maltreatment during childhood may recreate it in adulthood.

In terms of substance use, marijuana use was not a meaningful predictor for any of the dependent variables. However, hard drug use and binge drinking were significantly, if modestly, related to greater physical IPV perpetration. Neither sexual orientation nor relationship status was a particularly meaningful predictor of the dependent variables, although relationship status was significantly if slightly related to greater physical IPV victimization. A subsequent ANOVA comparison of means test (not shown in table format) revealed that married respondents scored higher on the physical IPV victimization index than did dating respondents (means: 1.30/dating vs. 1.50/married; $\mathrm{F}=6.87, p=0.00$ ). Mean Y1 scores for the two other relationship categories-engaged, married but separated-were higher than those for married respondents (1.57 and 1.87, respectively), but the sample sizes for both categories were below 30 so the individual means may be less reliable. Finally, prior arrests were significantly, if modestly, related to both physical IPV victimization and perpetration. None of the demographic-type control variables (race, education level, or age) were meaningfully predictive of any of the dependent variables.

\section{Discussion}

In their excellent article, Zweig et al. (2013) note that much work has been done on IPV including dating violence. However developments in social media and ECT leave areas ripe for exploration, such as how new technologies may facilitate a new method of abusing an intimate partner (i.e. electronically) (Zweig et al., 2013). While Zweig and colleagues focused on adolescents, the same point 
applies to young adults who may have moved beyond dating. To that end, this study sought to examine two research questions, specifically whether ECT usage, including ECT-facilitated aggression, increases IPV; and whether there are gender differences in ECT-facilitated IPV?

As to the first question, the results show that neither ECT-facilitated IPV victimization nor perpetration was a particularly robust or consistent predictor of physical or relational IPV. As to the role that gender plays in IPV and ECT-facilitated IPV, the results were mixed. Males had more IPV victimization and perpetration experiences; as well as physical and relational IPV. Males also often experienced greater ECT-facilitated IPV victimization; that is, males reported being monitored or controlled, or having a partner direct aggression towards them, by a romantic partner through social media platforms, than females reported. However, the results were often not significantly different from those of the female respondents. Despite the quantitative results, the female respondents were more expressive than the males in answering open-ended questions regarding current or past IPV victimization and perpetration experiences.

This study builds on two previous studies of ECT usage and IPV among dating adolescents. In a cross-sectional study of adolescents in US middle and high schools, Zweig et al. (2013) found that ECT-facilitated IPV often co-occurred with other dating violence; that males were more likely to report physical dating violence victimization; and that female teenagers were more willing to report their own IPV perpetration than male adolescents, as-the authors speculate-female-perpetrated aggression against a partner may be viewed as more acceptable than male-perpetrated aggression. Another study (Stonard et al., 2017) that involved focus groups with British teenagers found that female adolescents were more likely to report controlling or monitoring their dating partners through ECT. The present study found, like the adolescents in the Zweig et al. (2013) study, that young adult males also reported more physical IPV victimization than females. Young adult female respondents in the present study were also much more expressive about their current and past IPV perpetration, similar to the adolescent females of the Zweig et al. (2013) study; possibly for the reasons suggested by Zweig et al. (i.e. that IPV perpetration by females is more acceptable than that done by males).

Finally, as female adolescents in the Stonard et al. (2017) study reported monitoring and controlling dating partners via ECT; the young adult males in the present study generally reported more instances of their current dating partner monitoring or controlling them via ECT. Since the majority (93\%) of the males in the current study identified as strictly heterosexual, the implication is that the partners controlling or monitoring them via ECT were female. The implication is that IPV behaviors that surface during the adolescent dating years may similarly be a factor during young adulthood; and in fact be slightly more prevalent once a relationship status has changed from dating to marriage, as the current study found that more permanent relationship status (e.g. marriage) was related, if slightly, to IPV victimization and perpetration. This is only a supposition, 
however, as the current study is not longitudinal. The continuum of IPV behaviors from dating in adolescence into marriage in adulthood is an area for additional study.

The study's findings have implications for IPV prevention and intervention program planning. First, because communication via ECT is an extension of in-person communication between intimate partners, programs $s^{4}$ that increase awareness of appropriate vs. inappropriate ways to communicate would benefit participants. Much as many boys and men are often taught to "never hit a girl", an extension of that could be "it's not okay for anyone to hit their dating partner, fiancée, or spouse; or scream at them either in person or via text message or social media. It's not okay to post mean or abusive messages on your partner's social media, or text them mean or abusive messages on their cell phone". IPV programs that focus on maintaining healthy boundaries and reducing controlling behavior could extend those messages to also cover monitoring and controlling behaviors connected to ECT, such as demanding to have a partner's phone/email/social media passwords, reviewing their voice mail or text messages, and pestering them incessantly online. Prevention programming along these lines could begin in late elementary school when pre-teen children may have begun to use cell phones and social media accounts; and think about dating in the (near) future. Interventions, both for a general audience as well as individuals for which IPV has become an issue, could also be offered and incorporate material on appropriate ECT usage.

Second, since peer-related factors were strong predictors of IPV victimization and perpetration, prevention and intervention programs could aim to raise awareness of friends' behaviors and relationships; and how friend circles may normalize behavior that is, in fact, not healthy. Program participants could be asked to reflect on any aggression continuums in their behavior with regard to both friends and intimate partners; and how being aggressive towards an intimate partner may spark retaliatory aggression that causes them (greater) injury. Finally, given the "family factor" findings in the present study, IPV prevention and intervention programs could also have participants reflect on how their experiences growing up contribute to their interactions with past and current intimate partners; whether these interactions are healthy or risky; and how they may wish to change their communication and behavior in intimate relationships and break any cycle of violence they may have unwittingly learned while growing up.

While the present investigation makes contributions to the study of IPV, ECT and gender, some limitations must be acknowledged. First, the sample is limited to individuals who signed up with a service for the purpose of taking online surveys about various research topics. As such, the results may not be generalizable to the greater US population. The study is also cross-sectional rather than longitudinal, and as such it is not possible to observe any behavior changes over time. Additionally, the initial sample size was low and the age parameters needed to be ${ }^{4}$ See, for example, https://youth.gov/youth-topics/teen-dating-violence/electronic. 
adjusted to reach the target sample (or close to it).

\section{Conclusion}

In conclusion, despite its limitations the present study offers some insight into relationship violence and how it may be facilitated by new forms of technology, and inquiry about which is in the early stages. Future research could explore the same research questions using longitudinal data, to determine if cross-sectional findings hold up and how behavior (e.g. relationship aggression, electronic communication and social media usage) may change over time, such as in subsequent relationships that may be more permanent (i.e. marriage).

\section{Conflicts of Interest}

The author declares no conflicts of interest regarding the publication of this paper.

\section{References}

Ackard, D., Neumark-Sztainer, D., \& Hannan, P. (2003). Dating Violence among a Nationally Representative Sample of Adolescent Girls and Boys: Associations with Behavioral and Mental Health. Journal of Gender-Specific Medicine, 6, 39-48.

Adelman, M., \& Kil, S. H. (2007). Dating Conflicts. Rethinking Dating Violence and Youth Conflict. Violence against Women, 13, 1296-1318. https://doi.org/10.1177/1077801207310800

Archer, J. (2000). Sex Differences in Aggression between Heterosexual Partners: A Meta-Analytic Review. Psychological Bulletin, 126, 651-680. https://doi.org/10.1037/0033-2909.126.5.651

Arriaga, X. B., \& Foshee, V. A. (2004). Adolescent Dating Violence: Do Adolescents Follow in Their Friends', or Their Parents', Footsteps? Journal of Interpersonal Violence, 19, 162-184. https://doi.org/10.1177/0886260503260247

Barber, B. K., Olsen, J. E., \& Shagle, S. C. (1994). Associations between Parental Psychological and Behavioral Control and Youth Internalized and Externalized Behaviors. Child Development, 65, 1120-1136. https://doi.org/10.2307/1131309

Breiding, M. J., Smith, S. G., Basile, K. C., Walters, M. L., Chen, J., \& Merrick, M. T. (2014). Prevalence and Characteristics of Sexual Violence, Stalking, and Intimate Partner Violence Victimization-National Intimate Partner and Sexual Violence Survey, United States, 2011. Morbidity and Mortality Weekly Report, 63, 1-8. https://www.cdc.gov/mmwr/preview/mmwrhtml/ss6308a1.htm

Brooks-Russell, A., Foshee, V. A., \& Ennett, S. T. (2013). Predictors of Latent Trajectory Classes of Physical Dating Violence Victimization. Journal of Youth and Adolescence, 42, 566-580. https://doi.org/10.1007/s10964-012-9876-2

Cannon, C. E. B., \& Buttell, F. P. (2016). The Social Construction of Roles in Intimate Partner Violence: Is the Victim/Perpetrator Model the Only Viable One? Journal of Family Violence, 31, 967-971. https://doi.org/10.1007/s10896-016-9883-2

Cantos, A. L., Neidig, P. H., \& O’Leary, K. D. (1994). Injuries of Women and Men in a Treatment Program for Domestic Violence. Journal of Family Violence, 9, 113-124. https://doi.org/10.1007/BF01531958

Capaldi, D. M., Dishon, T. J., Stoolmiller, M., \& Yoerger, K. (2001). Aggression toward 
Female Partners by At-Risk Young Men: The Contribution of Male Adolescent Friendships. Developmental Psychology, 37, 61-73.

https://doi.org/10.1037/0012-1649.37.1.61

CDC Centers for Disease Control and Prevention, National Center for HIV/AIDS, Viral Hepatitis, STD, and TB Prevention, Division of Adolescent and School Health (2012). Youth Risk Behavior Surveillance System: Selected 2011 National Health Risk Behaviors and Health Outcomes by Sex. Atlanta.

http://www.cdc.gov/healthyyouth/yrbs/pdf/us_disparitysex_yrbs.pdf

Chase, K. A., Treboux, D., \& O’Leary, K. D. (2002). Characteristics of High-Risk Adolescents' Dating Violence. Journal of Interpersonal Violence, 17, 33-48. https://doi.org/10.1177/0886260502017001003

Coker, A. L., McKeown, R. E., Sanderson, M., Davis, K. E., Valois, R. F., \& Huebner, E. S. (2000). Severe Dating Violence and Quality of Life among South Carolina High School Students. American Journal of Preventive Medicine, 19, 220-227. https://doi.org/10.1016/S0749-3797(00)00227-0

Cunradi, C. B. (2009). Intimate Partner Violence among Hispanic Men and Women: The Role of Drinking, Neighborhood Disorder, and Acculturation-Related Factors. Violence and Victims, 24, 83-97. https://doi.org/10.1891/0886-6708.24.1.83

Cutbush, S., Williams, J., Miller, S., Gibbs, D., \& Clinton-Sherrod, M. (2018). Longitudinal Patterns of Electronic Teen Dating Violence among Middle School Students. Journal of Interpersonal Violence. https://doi.org/10.1177/0886260518758326 https://journals-sagepub-com.kean.idm.oclc.org/doi/pdf/10.1177/0886260518758326

Dobash, R. P., Dobash, R. E., Wilson, M., \& Daly, M. (1992). The Myth of Sexual Symmetry in Marital Violence. Social Problems, 39, 71-91. https://doi.org/10.2307/3096914

Dowd, L., Leisring, P., \& Rosenbaum, A. (2005). Partner Aggressive Women: Characteristics and Treatment Attrition. Violence and Victims, 20, 219-233. https://doi.org/10.1891/vivi.2005.20.2.219

Draucker, D. B., \& Martsolf, D. S. (2010). The Role of Electronic Communication Technology in Adolescent Dating Violence. Journal of Child and Adolescent Psychiatric Nursing, 23, 133-142. https://doi.org/10.1111/j.1744-6171.2010.00235.x

Feiring, C., Deblinger, E., Hoch-Espada, A., \& Haworth, T. (2002). Romantic Relationship Aggression and Attitudes in High School Students: The Role of Gender, Grade, and Attachment and Emotional Styles. Journal of Youth and Adolescence, 31, 373-385. https://doi.org/10.1023/A:1015680625391

Feld, S. L., \& Straus, M. A. (1989). Escalation and Desistance of Wife Assault in Marriage. Criminology, 27, 141-161. https://doi.org/10.1111/j.1745-9125.1989.tb00866.x

Ferree, M. M. (1990). Beyond Separate Spheres: Feminism and Family Research. Journal of Marriage \& Family, 52, 866-884. https://doi.org/10.2307/353307

Foshee, V. A., Benefield, T. S., Ennett, S. T., Bauman, K. E., \& Suchindran, C. (2004). Longitudinal Predictors of Serious Physical and Sexual Dating Violence Victimization during Adolescence. Preventive Medicine, 39, 1007-1016.

https://doi.org/10.1016/j.ypmed.2004.04.014

Foshee, V. A., Ennett, S. T., Bauman, K. E., Benefield, T., \& Suchindran, C. (2005). The Association between Family Violence and Adolescent Dating Violence Onset: Does It Vary by Race, Socioeconomic Status, and Family Structure? Journal of Early Adolescence, 25, 317-344. https://doi.org/10.1177/0272431605277307

Foshee, V. A., Reyes, H. L. M., \& Ennett, S. T. (2010). Examination of Sex and Race Differences in Longitudinal Predictors of the Initiation of Adolescent Dating Violence 
Perpetration. Journal of Aggression, Maltreatment, and Trauma, 19, 492-516. https://doi.org/10.1080/10926771.2010.495032

Giles-Sims, J. (1983). Wife Battering: A Systems Theory Approach. New York: Guilford Press.

Gorman-Smith, D., Tolan, P. H., Sheidow, A. J., \& Henry, D. B. (2001). Partner Violence and Street Violence among Urban Adolescents: Do the Same Family Factors Relate? Journal of Research on Adolescence, 11, 273-295. https://doi.org/10.1111/1532-7795.00013

Graham-Kevan, N., \& Archer, J. (2003). Intimate Terrorism and Common Couple Violence: A Test of Johnson's Predictions in Four British Samples. Journal of Interpersonal Violence, 18, 1247-1270. https://doi.org/10.1177/0886260503256656

Graham-Kevan, N., \& Archer, J. (2005). Investigating Three Explanations of Women's Relationship Aggression. Psychology of Women Quarterly, 29, 270-277. https://doi.org/10.1111/j.1471-6402.2005.00221.x

Halpern, C. T., Young, M. L., Waller, M. W., Martin, S. L., \& Kupper, L. L. (2004). Prevalence of Partner Violence in Same-Sex Romantic and Sexual Relationships in a National Sample of Adolescents. Journal of Adolescent Health, 35, 124-131. https://doi.org/10.1016/S1054-139X(03)00345-8

Hayes, B. E. (2013). Women's Resistance Strategies in Abusive Relationships: An Alternative Framework. SAGE Open, 3, 1-10. https://doi.org/10.1177/2158244013501154

Hettrich, E. L., \& O’Leary, K. D. (2007). Females' Reasons for Their Physical Aggression in Dating Relationships. Journal of Interpersonal Violence, 22, 1131-1143. https://doi.org/10.1177/0886260507303729

Howard, D. E., \& Wang, M. Q. (2003). Risk Profiles of Adolescent Girls Who Were Victims of Dating Violence. Adolescence, 38, 1-14.

Johnson, M. P. (2006). Conflict and Control: Gender Symmetry and Asymmetry in Domestic Violence. Violence against Women, 12, 1003-1018.

https://doi.org/10.1177/1077801206293328

Johnson, M. P. (2011). Gender and Types of Intimate Partner Violence: A Response to an Anti-Feminist Literature Review. Aggression \& Violent Behavior, 16, 289-296. https://doi.org/10.1016/j.avb.2011.04.006

Kelly, P. J., Cheng, A.-L., Peralez-Dieckmann, E., \& Martinez, E. (2009). Dating Violence and Girls in the Juvenile Justice System. Journal of Interpersonal Violence, 24, 1536-1551. https://doi.org/10.1177/0886260508323664

Kimmel, M. S. (2002). "Gender Symmetry" in Domestic Violence: A Substantive and Methodological Research Review. Violence against Women, 8, 1332-1363. https://doi.org/10.1177/107780102237407

Kinsfogel, K. M., \& Grych, J. H. (2004). Interparental Conflict and Adolescent Dating Relationships: Integrating Cognitive, Emotional, and Peer Influences. Journal of Family Psychology, 18, 505-515. https://doi.org/10.1037/0893-3200.18.3.505

Koss, M. P., Goodman, L. A., Browne, A., Fitzgerald, L. F., Keita, G. P., \& Russo, N. F. (1994). No Safe Haven: Male Violence against Women at Home, at Work, and in the Community. Washington DC: American Psychological Association. https://doi.org/10.1037/10156-000

Langhinrichsen-Rohling, J. (2010). Controversies Involving Gender and Intimate Partner Violence in the United States. Sex Roles, 62, 179-193. https://doi.org/10.1007/s11199-009-9628-2

Langhinrichsen-Rohling, J., \& Capaldi, D. M. (2012). Clearly We've Only Just Begun: 
Developing Effective Prevention Programs for Intimate Partner Violence. Prevention Science, 13, 410-414. https://doi.org/10.1007/s11121-012-0310-5

Langhinrichsen-Rohling, J., Neidig, P., \& Thorn, G. (1995). Violent Marriages: Gender Differences in Levels of Current and Past Abuse. Journal of Family Violence, 10, 159-176. https://doi.org/10.1007/BF02110598

Lavoie, F., Hébert, M., Tremblay, R., Vitaro, F., Vézina, L., \& McDuff, P. (2002). History of Family Dysfunction and Perpetration of Dating Violence by Adolescent Boys: A Longitudinal Study. Journal of Adolescent Health, 30, 375-383. https://doi.org/10.1016/S1054-139X(02)00347-6

Leadbeater, B. J., Banister, E. M., Ellis, W. E., \& Yeung, R. (2008). Victimization and Relational Aggression in Adolescent Romantic Relationships: The Influence of Parental and Peer Behaviors, and Individual Adjustment. Journal of Youth and Adolescence, 37, 359-372. https://doi.org/10.1007/s10964-007-9269-0

Lenhart, A., \& Madden, M. (2007). Teens, Privacy, and Online Social Networks. http://www.pewinternet.org/ /media/Files/Reports/2007/PIP_Teens_Privacy_SNS_Re port_Final.pdf.pdf

Lichter, E. L., \& McCloskey, L. A. (2004). The Effects of Childhood Exposure to Marital Violence on Adolescent Gender-Role Beliefs and Dating Violence. Psychology of Women Quarterly, 28, 344-357. https://doi.org/10.1111/j.1471-6402.2004.00151.x

Lormand, D. (2009). Is Dating Violence Associated with Substance Use and Sexual Risk Behaviors among Urban, Minority, Middle School Youth? Doctoral Dissertation, Houston, TX: Texas Medical Center Dissertations.

Miller, S. L., \& Meloy, M. L. (2006). Women's Use of Force: Voices of Women Arrested for Domestic Violence. Violence against Women, 12, 89-115.

https://doi.org/10.1177/1077801205277356

Molidor, C., \& Tolman, R. M. (1998). Gender and Contextual Factors in Adolescent Dating Violence. Violence against Women, 4, 180-194.

https://doi.org/10.1177/1077801298004002004

Mulford, C., \& Giordano, P. C. (2008). Teen Dating Violence: A Closer Look at Adolescent Romantic Relationships. National Institute of Justice Journal, 261, 34-40.

http://www.nij.gov/journals/261/teen-dating-violence.htm https://doi.org/10.1037/e504542009-005

O'Keefe, M. (2005). Teen Dating Violence: A Review of Risk Factors and Prevention Efforts.

https://www.semanticscholar.org/paper/Teen-Dating-Violence\%3A-A-Review-of-RiskFactors-and-O'keefe/572289d34f75fe46c6b819e8ab41ad8bb9aaacf6

O’Leary, K. D., Barling, J., Arias, I., Rosenbaum, A., Malone, J., \& Tyree, A. (1989). Prevalence and Stability of Physical Aggression between Spouses: A Longitudinal Analysis. Journal of Consulting and Clinical Psychology, 57, 263-268. https://doi.org/10.1037/0022-006X.57.2.263

Picard, P. (2007). Tech Abuse in Teen Relationships Study. New York, NY: Liz Claiborne Inc.

Reed, L. A., Ward, L. M., Tolman, R. M., Lippman, J. R., \& Seabrook, R. C. (2018). The Association between Stereotypical Gender and Dating Beliefs and Digital Dating Abuse Perpetration in Adolescent Dating Relationships. Journal of Interpersonal Violence, 28, 1-25. https://doi.org/10.1177/0886260518801933

Schnurr, M. P. (2009). Precursors to Adolescents' Dating Violence Perpetration and Healthy Romantic Relationships. Doctoral Dissertation, Ames, IA: Digital Repository 
at Iowa State University.

Schnurr, M. P., \& Lohman, B. J. (2013). The Impact of Collective Efficacy on Risks for Adolescents' Perpetration of Dating Violence. Journal of Youth and Adolescence, 42, 518-535. https://doi.org/10.1007/s10964-013-9909-5

Schwartz, M. D. (2000). Methodological Issues in the Use of Survey Data for Measuring and Characterizing Violence against Women. Violence against Women, 6, 815-838. https://doi.org/10.1177/10778010022182164

Smith, S. G., Chen, J., Basile, K. C., Gilbert, L. K., Merrick, M. T., Patel, N., Walling, M., \& Jain, A. (2017). The National Intimate Partner and Sexual Violence Survey (NISVS): 2010-2012 State Report. Atlanta, GA: National Center for Injury Prevention and Control, Centers for Disease Control and Prevention.

Stark, E. (2007). Coercive Control: The Entrapment of Women in Personal Life. New York: Oxford University Press.

Stith, S. M., Smith, D. B., Penn, C. E., Ward, D. B., \& Tritt, D. (2004). Intimate Partner Physical Abuse Perpetration and Victimization Risk Factors: A Meta-Analytic Review. Aggression and Violent Behavior, 10, 65-98. https://doi.org/10.1016/j.avb.2003.09.001

Stonard, K. E., Bowen, E., Walker, K., \& Price, S. A. (2017). They'll Always Find a Way to Get to You": Technology Use in Adolescent Romantic Relationships and Its Role in Dating Violence and Abuse. Journal of Interpersonal Violence, 32, 2083-2117. https://doi.org/10.1177/0886260515590787

Straus, M. A. (1979). Measuring Intrafamily Conflict and Violence: The Conflict Tactics (CT) Scales. Journal of Marriage \& Family, 41, 75-88. https://doi.org/10.2307/351733

Straus, M. A. (1983). Ordinary Violence, Child Abuse, and Wifebeating: What Do They Have in Common? In D. Finkelhor, R. J. Gelles, G. T. Hotaling, \& M. A. Straus (Eds.), The Dark Side of Families (pp. 213-234). Newbury Park, CA: Sage Publications.

Straus, M. A. (1999). The Controversy over Domestic Violence by Women: A Methodological, Theoretical, and Sociology of Science Analysis. In X. B. Arriaga, \& S. Oskamp (Eds.), Violence in Intimate Relationships (pp. 17-44). Thousand Oaks, CA: Sage. https://doi.org/10.4135/9781452204659.n2

Straus, M. A. (2004). Prevalence of Violence against Dating Partners by Male and Female University Students Worldwide. Violence against Women, 10, 790-811. https://doi.org/10.1177/1077801204265552

Straus, M. A., \& Gelles, R. J. (1986). Societal Change and Change in Family Violence from 1975 to 1985 as Revealed by Two National Surveys. Journal of Marriage and the Family, 48, 465-479. https://doi.org/10.2307/352033

Straus, M. A., Hamby, S. L., Boney-McCoy, S., \& Sugarman, D. B. (1996). The Revised Conflicts Tactics Scale (CTS2): Development and Preliminary Psychometric Data. Journal of Family Issues, 17, 283-316. https://doi.org/10.1177/019251396017003001

Stuart, G. L., Moore, T. M., Coop Gordon, K., Hellmuth, J.C., Ramsey, S. E., \& Kahler, C. W. (2006). Reasons for Intimate Partner Violence Perpetration among Arrested Women. Violence against Women, 12, 609-621. https://doi.org/10.1177/1077801206290173

Swahn, M. H., Simon, T. R., Arias, L., \& Bossarte, R. M. (2008). Measuring Sex Differences in Violence Victimization and Perpetration within Date and Same-Sex Peer Relationships. Journal of Interpersonal Violence, 23, 1120-1138.

https://doi.org/10.1177/0886260508314086

Swan, S. C., Gambone, L. J., Caldwell, J. E., Sullivan, T. P., \& Snow, D. L. (2008). A Review of Research on Women's Use of Violence with Male Intimate Partners. Violence and Victims, 23, 301-314. https://doi.org/10.1891/0886-6708.23.3.301 
Swan, S., \& Snow, D. L. (2002). A Typology of Women's Use of Violence in Intimate Relationships. Violence against Women, 8, 286-319. https://doi.org/10.1177/107780120200800302

Swart, L. A., Seedat, M., Stevens, G., \& Ricardo, I. (2002). Violence in Adolescents' Romantic Relationships: Findings from a Survey amongst School-Going Youth in a South African Community. Journal of Adolescence, 25, 385-395. https://doi.org/10.1006/jado.2002.0483

Tontodonato, P., \& Crew, B. K. (1992). Dating Violence, Social Learning Theory, and Gender: A Multivariate Analysis. Violence and Victims, 7, 3-14.

UCLA Center for Communication Policy (2003). The UCLA Internet Report: Surveying the Digital Future Year 3.

https://www.digitalcenter.org/wp-content/uploads/2013/02/2003_digital_future_report -year3.pdf

United States Department of Labor, Bureau of Labor Statistics (2013). The NLSY97. National Longitudinal Surveys. http://www.bls.gov/nls/nlsy97.htm

Vega, E. M., \& O’Leary, K. D. (2007). Test-Retest Reliability of the Revised Conflict Tactics Scales (CTS2). Journal of Family Violence, 22, 703-708.

https://doi.org/10.1007/s10896-007-9118-7

Vézina, J., \& Hébert, M. (2007). Risk Factors for Victimization in Romantic Relationships of Young Women: A Review of Empirical Studies and Implications for Prevention. Trauma, Violence, \& Abuse, 8, 33-66. https://doi.org/10.1177/1524838006297029

White, J. W., \& Kowalski, R. M. (1994). Deconstructing the Myth of the Nonaggressive Woman. Psychology of Women Quarterly, 18, 487-508. https://doi.org/10.1111/j.1471-6402.1994.tb01045.x

Widom, C. S. (1989). The Cycle of Violence. Science, 244, 160-166. https://doi.org/10.1126/science.2704995

Wolf, K. A., \& Foshee, V. A. (2003). Family Violence, Anger Expression Styles, and Adolescent Dating Violence. Journal of Family Violence, 18, 309-316. https://doi.org/10.1023/A:1026237914406

Yan, F. A., Howard, D. E., Beck, K. H., Shattuck, T., \& Hallmark-Kerr, M. (2010). Psychosocial Correlates of Physical Dating Violence Victimization among Latino Early Adolescents. Journal of Interpersonal Violence, 25, 808-831. https://doi.org/10.1177/0886260509336958

Yllo, K. (2005). Through a Feminist Lens: Gender, Diversity \& Violence-Extending the Feminist Framework. In D. R. Loseke, R. J. Gelles, \& M. M. Cavanaugh (Eds.), Current Controversies on Family Violence (pp. 19-34). Newbury, CA: Sage. https://doi.org/10.4135/9781483328584.n2

Zweig, J. M., Dank, M., Yahner, J., \& Lachman, P. (2013). The Rate of Cyber Dating Abuse among Teens and How It Relates to Other Forms of Teen Dating Violence. Journal of Youth and Adolescence, 42, 1063-1077.

https://doi.org/10.1007/s10964-013-9922-8 